\title{
THE EFFECT OF DETERMINING HIGHEST RETAIL PRICE BASED ON FUTURE RICE PRODUCTION CONDITIONS IN THE CITY OF PALEMBANG, INDONESIA
}

\author{
Limbolon Karimullah, Mulyana Andy, Riswani \\ Masters Program in Agribusiness, Faculty of Agriculture, University of Sriwijaya, Indonesia \\ *E-mail: andy sep@yahoo.com
}

\begin{abstract}
This study was conducted Palembang province of South Sumatra. Election where this research was done intentionally (purposive) considering Palembang is the capital Province South Sumatra who consistently maintain rice land area. this study was a survey method through observation, interviews, and filling out questionnaires relating to the analysis of farmer income and the influence of production factors on the amount of rice production in the period before and after setting the highest retail price of rice. From the results of the study, a future strategy to increase rice production in Palembang City will be formulated so that the total sample taken is 180 farmers. The results of this study are known factors that affect rice production in the city of Palembang, which is significant, namely land area, pesticides, seed costs, working days, and the highest retail price.
\end{abstract}

\section{KEY WORDS}

Production, rice, highest retail price, farmer income.

The need for rice in Indonesia will increase every year along with the increasing rate of growth in Indonesia's population. Dependence most indonesian are very high on rice would be a problem if it is out of rice availability can be provided and it is which can inteerfere with the resilience of food and train. In addition, rice is also a very strategic political commodity, co that domestic rice production benchmarks of food availability for indonesia (Hidayat, 2012).

Therefore, it was not surprising that the Indonesian goverment's intervention is very large in efforts to increase production and price stability. Food sufficiency (especially rice) at an affordable price has become the main objective of agricultural development policy. Food shortages can cause economic, social and political insecurity that can destabilize national stability. The central government to government level provinces and districts or cities throughout Indonesia should strive to increase their agricultural production, including South Sumatra province.

South Sumatra was one of the provinces in Indonesia which has a big influence in the production of food and train is not independent of the availability of potential land resources varied enough to be planted commodity food. One of the region in the south sumatera province, although not the area producer of food, but also has a contribution in the provision of food in the province of South Sumatra is the city of Palembang.

For that, the area of Palembang continue to strive to maintain the agricultural land area that had the type of rice field and many lowland encountered in the outskirts of the city. The lebak paddy fields are mostly spread in 10 districts. As for the sub-district, they are; West IIIr District (IB) I, IB II, Gandus, Seberang Ulu (SU) I, Seberang Ulu (SU) II, Kertapati, Kalidoni, Plaju, llir Timur II, and Sematang Borang.

Palembang City was a city that has many tributaries, so that many contours of the land are swamp or lebak. It is very fortunate that for a long time people have developed swampy swamp farming so that the balance of nature can still be maintained. With an area of 5,734 hectares of swampy agricultural land, the city of Palembang hopes to play a role in the Rice Special Efforts (UPSUS) in South Sumateta, which is to optimize the total land area of $1,241,700$ hectares. From the extent of exploitaton ofthe fields mentioned, recorded production which generated Palembang in the period of five years of the lastt relatively still fluctuated, but with a tedency to rice, such as that prsented in table 1 below it. 
Table 1 - Total Production of GKP in Palembang City in 2012-1018

\begin{tabular}{|c|c|c|c|c|c|c|c|}
\hline \multirow{2}{*}{$\begin{array}{l}\text { shape } \\
\text { comodity }\end{array}$} & \multicolumn{7}{|c|}{ Tahun } \\
\hline & 2012 & 2013 & 2014 & 2015 & 2016 & 2017 & 2018 \\
\hline GKP production (tons) & 28,83 & 29,63 & $19,09^{\prime}$ & $25,91^{\top}$ & $29,92^{7}$ & 27,36 & 34,48 \\
\hline Grain Productivity (tons/ha) & 4,58 & $4,80^{*}$ & $4,30^{\circ}$ & $4,14^{*}$ & $4,89^{\circ}$ & $4,77^{*}$ & 5,21 \\
\hline
\end{tabular}

Source: Palembang City Agriculture and KP Office (2019)

Table 1, shows the results of production and productivity in the form of rice that has been converted to rice in Palembang City from 2010-2016, which is still fluctuating. According to BPS data for 201, this production result is quite good compared to other cities / districts on the island of Sumatra which have an average productivity of 4.5 tons of harvested unhusked rice (GKP) / hectare. The difference in productivity with other regions, especially agriculture in Java, is due to various factors including; rice field type, soil type or characteristics, level of management, and rice varieties planted. Likewise, the types or types of paddy fields consisting of irrigated fields, rain-fed rice fields, tidal fields, and lebak fields.

Potential grain yield obtained in the tidal and lowland rice fields by applying appropriate management technology can reach 4.5 - 5.5 tons / hectare. The strategies to increase rice production / year and rice productivity / hectare are carried out through; (1) application of existing technology optimally so that it can increase the annual planting index (IP), and (2) an increase in the area of rice fields due to the existence of lands / gardens, fields / huma and land which is temporarily not cultivated in Palembang City.

In 2018, 34.48 tons of rice milled in Palembang City will produce 20.69 tons of rice. This amount of production is still far from the need for rice every year in the city of Palembang. Based on the results of the national socioeconomic survey by the Central Statistics Agency (BPS, 2015), it states that rice consumption per capita is $98 \mathrm{~kg} /$ year, meaning that the population of Palembang City in 2018 of 1,602,071 people requires 157,313 tons of rice each year. With rice production of 20.69 tons in 2016 , Palembang City is still deficit of 136,623 tons of rice to be able to provide staple food for the people of Palembang City. This deficiency amount dikh a watirkan will continue to grow each year as a result; (1) the possibility of the conversion of paddy fields to housing, industrial estates, and road infrastructure as a direct consequence of the population growth rate in Palembang City each year, and (2) the decline in rice production due to the reduced interest of farmers to farm as a result of the implementation of government policies about the highest retail price (HET) of rice Increasing rice production in the city of Palembang can be through intensification and extensification. Increased rice production through intensification, such as; (1) the optimal application of existing technology, and (2) an increase in planting area through an increase in the planting index (IP) and opening of new areas. Increased rice production by extensification is the addition of paddy fields through the opening of new paddy fields. The addition of rice fields in Palembang is still very possible because there is still unused temporary land area of 3.163 hectares, and spread across several districts, among them is that there are in; (1) Gandus District, which is 2,380 hectares, (2) llir Barat I District is 320 hectares, (3) Sematang Borang District is 211 hectares, (4) Kertapati District is 118 hectares, (5) Sako District is 75 hectares, and several hectares in other districts in the city of Palembang.

However, the determination of the highest retail price (HET) of rice tends to disadvantage farmers as producers, because it is feared that the policy will affect grain prices at the upstream level or farmers. In addition, the policy of the highest retail price (HET) of rice results in changes in the price of rice on the consumer or downstream markets, and this will affect the price of grain at the farm level. The implementation of the highest retail price policy (HET) for rice has not anticipated various problems faced by farmers such as the fluctuating amount of production costs that is affected by the prices of fertilizers, agricultural equipment, seeds, and the change of seasons. An example is usually the level of rice production in the dry season is low, while the production costs are high. Meanwhile, with the determination of the highest retail price (HET) of rice, the selling price of rice will remain 
in accordance with the determination. That is, farmers will suffer losses because they sell at higher prices as the only perform ad price takers.

\section{LITERATURE REVIEW}

Empirical research proves that the relationship between the price of agricultural production at the consumer level and at the producer (farmer) level is asymmetrical Simatupang (1989) in_Jamal, et al. , (2007). This means, an increase in the price of rice at the consumer level is transmitted imperfectly and slowly to the price of grain at the farm level, while a decrease in the price of rice at the consumer level is transmitted perfectly and quickly to the price of grain at the farm level. Conversely, an increase in grain prices at the farm level is transmitted perfectly and quickly to the price of rice at the consumer level, while a decrease in grain prices at the farm level is transmitted by price policies and their impact on food security. Strengthen the ability of food self-sufficiency imperfectly and slowly to the price of rice at the consumer level.

\section{METHODS OF RESEARCH}

The method used in this study was a survey method through observation, interviews, and filling out questionnaires relating to the analysis of farmer income and the influence of production factors on the amount of rice production in the period before and after setting the highest retail price (HET) of rice. In research, later formulated the strategy of increasing rice production forward in Palembang.

\section{RESULTS AND DISCUSSION}

Linear regression analysis is a method used to analyze the relationship between variables. This relationship can be expressed in terms of an equation that relates the dependent variable $\mathrm{Y}$ (dependent) with one or more independent variables $\mathrm{X} 1, \mathrm{X} 2, \ldots, \mathrm{Xk}$ (independent). When there is only one variable $b$ ebas (independent), it is called a simple linear regression model and free variable (independent) more than one, then it is called multiple linear regression model (Nachrowi, 2008). The relationship between dependent variables is freely expressed in the form of mathematical equations which state the functional relationship between variables.

Determination of independent and dependent require study careful, thorough discussion, various kinds of considerations, the reasonableness of the problems encountered and the experience will help facilitate the determination. Variables that are easily obtained/ available are often classified as independent variables (independent) while variables occur because the independent variables are dependent variables (Sudjana, 2005).

A general form of multiple linear regression equations can be written as follows:

$$
Y=\alpha+\beta_{1} X_{1}+\beta_{2} X_{2}+\beta_{3} X_{3}+\beta_{4} X_{4}+\beta_{5} X_{5}+\beta_{D} D
$$

Where: $\mathrm{Y}=$ Variable explained (rice production); $\mathrm{A}=$ constant $/$ intercept; $\mathrm{X}_{1}=$ Land area (ha); $X_{2}=$ Seed cost $(\mathrm{kg}) / \mathrm{ha} ; X_{3}=$ Fertilizer cost $(\mathrm{kg}) / \mathrm{ha} ; X_{4}=$ Pesticides cost $(\mathrm{kg}$ or It) / ha; $X_{5}=$ Labor cost $(H K O) /$ ha; $D=$ Before (0) and after (1) HET (Dummy variable); $\alpha=$ Constant.

The results of the calculation of the coefficient of determination based on analysis with the help of SPSS for windows version 16.0 as shown in the table 2. In accordance with the results of the analysis, the results of equation as follows:

$$
\begin{gathered}
\mathrm{Y}=4117,517-0.065{ }^{*} \text { Area }+0,001 \text { * Seed Cost }+0,001{ }^{*} \text { Fertilizer Cost }-0,001 \text { * Pesticide cost }+ \\
5,973 \text { * Total_HOK }-188,305 \text { * Dummy }
\end{gathered}
$$


Table 2 - Results of Multiple Linear Regression Analysis

\begin{tabular}{|c|c|c|c|c|c|c|c|c|}
\hline & Coefficients $^{a}$ & & & & & & & \\
\hline \multirow{2}{*}{ No } & \multirow{2}{*}{ Model } & \multicolumn{2}{|c|}{$\begin{array}{l}\text { Unstandardized } \\
\text { Coefficients }\end{array}$} & \multirow{2}{*}{$\begin{array}{l}\text { Standardized } \\
\text { Coefficients } \\
\text { Beta }\end{array}$} & \multirow{2}{*}{$t$} & \multirow{2}{*}{ Sig. } & \multicolumn{2}{|c|}{$\begin{array}{l}95,0 \% \text { Confidence Interval } \\
\text { for B }\end{array}$} \\
\hline & & $\mathrm{B}$ & Std. Error & & & & $\begin{array}{l}\text { Lower } \\
\text { Bound }\end{array}$ & $\begin{array}{l}\text { Upper } \\
\text { Bound }\end{array}$ \\
\hline 1 & (Constant) & 4117,517 & 233,697 & & 17,619 & 000 & 3657,898 & 4577,136 \\
\hline 2 & $\begin{array}{l}\text { Land Area } \\
\text { paddy (ha) }\end{array}$ &,- 065 & 74,519 & ,000 &,- 001 & ,999 & $-146,622$ & 146,493 \\
\hline 3 & Seed cost & ,001 &, 000 & ,115 & 2,284 & ,023 &, 000 &, 001 \\
\hline 4 & Fertilizer cost & ,001 &, 000 & ,314 & 7,099 &, 000 & ,000 & ,001 \\
\hline 5 & Pesticides cost &,- 001 & ,000 &,- 478 & $-9,402$ & ,000 &,- 001 &, 000 \\
\hline 6 & $\mathrm{HOK}$ & 5,975 & 5,241 &, 054 & 1,140 & ,255 & $-4,332$ & 16,282 \\
\hline 7 & KOD_HET & $-188,305$ & 59,663 &,- 130 & $-3,156$ &, 002 & $-305,646$ & $-70,964$ \\
\hline
\end{tabular}

Regression equation has the meaning: Seed costs have a significant and positive effect on rice production with a probability value of 0.001 , which means that each additional seed cost of Rp. 1 will increase rice production by $0.001 \mathrm{~kg}$ (or each additional seed cost of Rp. 1,000 will increase rice production by $1 \mathrm{~kg}$ ). Fertilizer costs significantly influence rice production with a probability value of 0.001 , which means that each additional fertilizer cost of $\mathrm{Rp}$. 1 will increase rice production by $0.001 \mathrm{~kg}$ (or each additional fertilizer cost of Rp. 1,000 will increase rice production by $1 \mathrm{~kg}$ ).

The cost of pesticides has a significant effect on rice production with a probability value of -0.001 , which means that each additional cost of pesticides by $\mathrm{Rp}$. 1 , will reduce rice production by $0.001 \mathrm{~kg}$ (or each additional cost of pesticides by Rp. 1,000 will increase rice production by $1 \mathrm{~kg}$ ). The application of the Highest Retail Price (HET) of rice has a negative effect on rice production with a probability value of $-188,305$. Land Area Paddy Variable $\left(X_{1}\right)$, From the results of econometrical estimationing it reveals that $t$-test results for a wide variable $\left(\mathrm{X}_{-1}\right)$ obtained a yield of,- 001 with probability equal to 0.999 . Land area probability value $\left(X_{1}\right)$ is greater than 0.05 so the $t$ count was no significant influence of land area $\left(X_{1}\right)$ with rice production $(Y)$, assuming other variables remain. Seed Cost Variable $\left(X_{2}\right)$, T-test results is obtained results of 2.284 with a probability of 0.023 lower than 005 , thus the results of $t$ arithmetic indicate there is a significant effect between the cost of seeds $\left(X_{2}\right)$ with rice production $(\mathrm{Y})$.

Pesticides cost Variable $\left(X_{3}\right), T$ test results for the variable obtained a result of 7.099 with a probability of 0,000 which is lower than 0.005 , thus the results of the t-test showed that there was a significant effect between the cost of fertilizer $\left(\mathrm{X}_{3}\right)$ and rice production $(\mathrm{Y})$. T-test results for the variable cost of pesticides $\left(X_{4}\right)$ obtained a yield of -9.402 with probability 0,000 lower than 0.005 , thus the t-test results showed no significant effect of the cost of pesticides $\left(\mathrm{X}_{4}\right)$ and rice production $(\mathrm{Y})$.

HOK Variable $\left(\mathrm{X}_{4}\right)$, T-test results is obtained a yield of 1.140 with 0.255 higher probability of 0.005 , thus no significant influence between the variables $\mathrm{HOK}\left(\mathrm{X}_{4}\right)$ on rice production (Y). HET Variable $\left(\mathrm{X}_{5}\right)$, T-test results for the application of HET obtained a result of -3.156 with a probability of 0.002 which is lower than 0.005 , thus there is a significant effect between the variables of HET implementation with rice production (Y).

Table 3 - Test Results The coefficient of determination $\left(R^{2}\right)$

\begin{tabular}{|c|c|c|c|c|}
\hline \multicolumn{4}{|c|}{ Model Summary } \\
\hline Model & $\mathrm{R}$ & R Square & Adjusted R Square & Std. Error of the Estimate \\
\hline 1 &, $638^{\mathrm{a}}$ &, 407 &, 396 & 562,7337621 \\
\hline a. Predictors: (Constant), KOD_HET, X2_NEW, HOK, fertilizer cost, land area paddy(ha), pestisides cost \\
\hline
\end{tabular}

The coefficient of determination was a concise measure that informs how much the change in the independent variable is in explaining the change in the dependent variable. The higher the coefficient of determination, the better the ability of independent variables in explaining the behavior of the dependent variable (Gujarati and Porter, 2009). 
The model used has an $\mathrm{R}^{2}$ coefficient of 0.407 which can be interpreted that the independent variable used in the model can only explain $40.7 \%$ of rice production while $59.3 \%$ of rice production is explained by other variables not included in the model. This small $R^{2}$ value indicates that further research is still needed on the factors that influence rice production in the swampy paddy fields in Palembang City. According to Djafar ( 2013) one of the main obstacles to developing farming in swamps is in undation during the rainy season and drought in the dry season which can not be predicted yet.

The problem of standing water in the rainy season and drought in the dry season is difficult for farmers to overcome individually, because excess water or drought does not only occur on individual land, but in one stretch so that the role of the City Government is highly expected to regulate water management in swamps lebak (Guswara and Widyantoro 2012), Management of location specific species of nutrient is also an obstacle in efforts to increase rice production because farmers use no fertilizer based on soil nutrient availability and crop needs, but based on farmers' economic capacity. This needs to get attention. Besides water and nutrient constraints, rat pest, brown plant hopper, stem borer, and blast disease (leaf blast and leuk er) also become technical obstacles in the cultivation of pa in swampy swamp land. Economic and social constraints are also found in farming activities in lebak swamps, such as limited capital, labor strength, and the low level of education of farmers.

\section{CONCLUSION}

Factors that have been proven to have a significant effect on farmers' rice production are fertilizer costs, seed costs, pesticide and dummy costs. Based on the results of the research it is suggested that rice farmers are expected to be able to increase production in Palembang by utilizing assistance or programs from the Government, both Palembang City, South Sumatra Province and the Department of Agriculture, especially in; (1) procurement of superior seeds, fertilizers, pesticides (medicines), (2) utilizing agricultural extension workers (PPL) to obtain the latest knowledge. So that after determining the highest retail price (HET) of rice, the farmer can increase his income, and the need for further research with a broader scope in order to be able to infer factors of production (independent variables) other than; seeds, fertilizers, pesticides and determination of HET of rice that affect rice production in the city of Palembang.

\section{REFERENCES}

1. Adiwilaga. 2004. Agricultural Business Science. Bandung: Alumni.

2. Agustinus Sri Wahyudi. 2010. Strategic Management. Binarupa Aksara. Jakarta.

3. Arikunto, Suharsimi. 2006. Research Procedure: A Practice Approach. Rineka Cipta.

4. Central Bureau of Statistics. 2009. Indonesian Statistics. BPS, Jakarta.

5. Central Bureau of Statistics. 2015. Data on Rice Consumption per Capita. CPM. Jakarta.

6. South Sumatra BPS. 2017. Annual Agriculture Statistics (SP) Results.

7. Palembang City BPS. 2013. Number of Agriculture Business Households by District and Plant Type, ST 2013.

8. Palembang City BPS. 2017. Projection of Indonesian Population 2010-2020.

9. Palembang City BPS. 2017. Number of Production of Rice in Palembang in 2010-1016.

10. Palembang City BPS. 2017. Projection of Indonesian Population 2010 - 2020.

11. Palembang City BPS. 2017. The Area of Tegal / Gardens, Fields / Humans and Temporary Land Not Cultivated According to Critics in the City of Palembang in 2015.

12. Buchori Alma. 2013. Introduction to Business. Alfabeta: Bandung

13. David FR 2001. Strategic Management, 8th Edition. Prentice Hall, Inc. Upper Saddle River, New Jersey. Subtitles Drs. Alexander Sindoro. PT. True Diamonds of Klaten.

14. David, FR 2006. Strategic Management. Jakarta, Indonesia: Publisher Salemba Four.

15. Ministry of Agriculture of the Republic of Indonesia. 2002. Guidelines for Growing Rice, Palawija, and Vegetable Plants. Jakarta: Bimas Control Agency. 